UDC 332.2.01

\title{
THE INSTITUTIONAL THEORY TREND OF LAND ORGANIZATION AND LAND PLANNING DEVELOPMENT
}

A. Tretiak, Doctor of Economic Sciences, Professor, Bila Tserkva National Agrarian University

ORCID ID: 0000-0002-1154-4797

V. Tretiak, Doctor of Economic Sciences, Professor, Sumy National Agrarian

University

ORCID ID: 0000-0001-6779-1941

T. Priadka, PhD in Economics, Associate Professor, Head of the Department of Land Resources Management and Cadastre, Bila Tserkva National Agrarian University

ORCID ID: 0000-0002-6179-0128

N. Kapinos, $\mathrm{PhD}$ in Economics, Sumy National Agrarian University

ORCID ID: 0000-0002-9354-5311

Abstract. Land planning specialization of land relations and land use system has significantly strengthened the role and place of land planning activities in the development of the country's economy and its territories. However, the theory of land organization and land planning does not keep up with the demands of practice. The functions, subject and objects of land organization and land planning are declared to a limited extent. Therefore, the purpose of the study is to substantiate the current development of land organization and land planning in Ukraine on the basis of the latest institutional and behavioral economic theory. It is substantiated that land planning activity is a socio-economic institution that provides trust, understanding and in the socio-economic area, through professional processing, submission and interpretation for users of land information about the facts and processes of organizations (institutions). In the narrow sense the land planning is the Institution of transformation using specific methods, rules (its formal component) and professional skills and judgments (informal component of the institution) of land managing facts in the language of numbers for understanding and manageability of all subjects of the socio-economic area. In a broad sense, land planning as an institution forms a certain face of land-tenure and land-use, state land institutions, public and other organizations (institutes) who organize and manage the use and protection of land and other natural resources and provide important informational content of local, 
regional, national and global socio-economic areas. The institution of land planning is primarily characterized by the state of the informal component, its ability to influence the adoption and compliance with the «rules of the game» through «organizations-institutions» (primarily associations of professional land surveyors). Influence the effective representation of management and economic activities related to land in society. This increase in theoretical ideas opens up new ways to develop land planning and, consequently, land reform measures. Its scientific and legal components («rules of the game») are increasingly based on ideas, the influence of the professional environment, which should become more and more organizationally united. On the other hand, the institutional theory of land planning opens the possibility and substantiates the need for the use of state regulatory bodies, scientific schools, professional associations of land surveyors, the ideology of «land planning engineering» and «land planning imperialism» in land policy.

Keywords. Institutional theory, land organization, land planning, land planning science, land planning activities.

Topicality. There is a serious problem in modern land management. The issue is the discrepancy of land organization and land planning practices with their theory. In today's practice, land organization and land planning are combined into surveying (geodetic and cadastral surveys) but not to the formation of market-oriented land management, scientifically sound distribution (redistribution) of land, capitalization and ecologization of land use, improving the quality of life of the country's population. Occupying an important place in the land management and land use of economic entities, land management has not become an important tool in making government decisions, decisions in the land and land capital market. In particular, taking a leading role in the implementation of the first stage of land reform (19902000), land planning has not outgrown from a system of land surveying to a system of capitalization, ecologization and an integrating part of social-economic space within territorial communities, regions and the country as a whole. At the same time, land management specialization of land relations and land use system has significantly strengthened the role and place of land planning activities in the 
development of the country's economy and territories. However, the theory of land organization and land planning does not keep up with the requests of practice. The functions, subject and objects of land organization and land planning are limitedly declared. Methodological innovations, for example in the issues of modeling land relations and forms of land use, assessment of land potential and capital, land use efficiency, do not have sufficient fundamental justifications.

Analysis of recent research and publications. Problems of modern development of land management and land management in Ukraine on the basis of institutional economic theory are considered in the works of A Tretiak, V Tretiak [1, 2], which emphasizes the need for a systematic, institutional approach to the analysis of the theory of land organization and land planning.

The purpose of the study is to substantiate the modern development of land organization and land planning in Ukraine on the basis of the newest institutionalbehavioral economic theory.

Research results and their discussion. The discrepancy between practice and theory is, first of all, a problem of land management science, which remains with a weak version of the theory. The development of land management science is logically connected with the development of social-behavioral science, including economics. Economics today also has a weak version of the theory. However, it is much more powerful than land management science and generates new methods and visions. Institutional analysis and behavioral methods have taken an important role in the development of economics. The institutional theory developed by economists is recognized in the world scientific environment and is applied in practice. Land surveyors also have initial research in institutional areas. By this time the corresponding paradigm has not been formed that would allow us to talk about a new - institutional theory of land organization and land planning.

For the first time in Ukraine, the basicity of the updated theoretical justification for reforming the domestic system of land organization and land planning was stated in 2008 in the Concept of improving land relations in Ukraine [3]. This Concept provided the tasks of scientific support for the development of a new, effective for 
national needs, the theory of development of land relations and land organization and land planning. After all, it was found out that the main reason for the poor effectiveness of land reform is underdevelopment of economic and environmental relations of land ownership, land management system in general, and in particular land management and land cadastre. This condition is due solely to the limited standard, technical and information process of land relations and land use management, and not as a more influential economic phenomenon, the effectiveness of which depends primarily on socio-cultural psychotypes of politicians, economists, ecologists, lawyers, land managers and other professionals, the level of their ability to self-organize and influence the implementation and formation of "rules of the game".

Finding out the importance of social influence on land management practice and science encourages the development of the theory of land organization and land planning on the bases of economic institutional and behavioral theory. The choice of this direction of research is due to close research of a number of leading scientists of Western scientific schools [4]. Forming a philosophical platform for the development of institutional-behavioral theory of land organization and land planning, we considered current trends of practice and fundamental developments of scientific schools that explore land organization and land planning from a "closed" information technology system to a significant phenomenon of national and global socioeconomic spaces.

INSTITUTIONS OF LAND PLANNING (LAND RELATIONS, LAND ORGANIZATION AND LAND USE

basicity of neoclassical and institutional theory of land planning

\begin{tabular}{c}
$\begin{array}{c}\text { Institutional } \\
\text { економічна } \\
\text { theory }\end{array}$ \\
\hline $\begin{array}{c}\text { Neoclassical } \\
\text { theory } \\
\text { Iand relations, land organization } \\
\text { and land use }\end{array}$ \\
$\begin{array}{c}\text { (A. Podolinsky, P. Pershin, V. Pareto } \\
\text { I. Kaufmann, Paul Van der Molen) }\end{array}$
\end{tabular}


Fig.1. Theoretical components of the growth of the essence of land planning from the "System" to the "Institution" (research hypothesis) dogmas.

In fig. 1 summarizes the basis of the hypothesis of our research - classic and modern theories of land organization formed the basis of perception of the phenomenon of land planning as a technical and economic "System", and positivist and institutional theoretical innovations should explain its current growth to the level of socio-economic "Institution".

It is the movement of land organization and land planning from one of the functions of land management to a more important and independent phenomenon in economics and ecology, which is substantiated by the institutional-behavioral theory of land organization and land planning. Within the framework of normative theories, the development of the socio-economic essence of land organization and land planning available in practice is not explained, and moreover, is limited to theoretical.

Applying the methods of analysis and synthesis to the consideration of modern land organization and land planning as a social phenomenon, we concluded that land management science meets all the theoretical features of social and behavioral science in general and economic institutions in particular.

The table 1 shows the main criteria of institutions in these theories, each of which fully corresponds to the phenomenon of "land organization and land planning". Moreover, the phenomenon of "land planning" corresponds to all the features characteristic of social institutions (Table 2). Based on the provisions set out in tables 1 and 2, we can say that land management is a special phenomenon in the socioeconomic space, and is a separate institution and the Institute of this space. The terms "institute of education", "institute of medicine", "institute of justice" and others are widely used in the scientific literature.

It is time to explain and use the concept of "Institution and Institute of Land Management" (Fig. 2). In social and economic theories, the concepts of "Institution" and "Institute" are a complex and multifaceted phenomenon. Each scientific direction of institutional theory ("old", "new" institutionalism, its various doctrines) complement and deepen the essence of the concept of Institution and Institute. One of 
the most capacious and accepted definitions was given by the founder of this theory, Jeffrey Hodgson: "Institutions are both objectively existing formations that are" somewhere outside" and subjective "springs" of human activity in people's heads" [5].

Table 1. Correspondence of the phenomenon "land organization and land planning" to the criteria of institutions in economic and social theories

\begin{tabular}{|c|c|}
\hline \multicolumn{2}{|c|}{ The main criteria of institutions in theories } \\
\hline $\begin{array}{l}\text { Sociology: } \\
\text { 1) Formation of relations between } \\
\text { people within the economic space of } \\
\text { ownership and land use; } \\
\text { 2) Social practice is regular and long- } \\
\text { term (indefinite); } \\
\text { 3) Depersonalized system; } \\
\text { 4) Normative and stable but complicated } \\
\text { practice, subject to broad social control. }\end{array}$ & $\begin{array}{l}\text { Economy: } \\
\text { 1) Maximizing the usefulness of the } \\
\text { functioning of land organization and } \\
\text { land use measures; } \\
\text { 2) Reduction of uncertainty (through the } \\
\text { formation of land information space); } \\
\text { 3) The impact of land organization and } \\
\text { land planning on the economy of land } \\
\text { use; } \\
\text { 4) Clear definition of functions and } \\
\text { tasks of land organization and land } \\
\text { planning; } \\
\text { 5) The complexity of the phenomenon } \\
\text { of "land organization and land planning" } \\
\text { - a set of institutions and institutions that } \\
\text { have historically functioned as a whole. }\end{array}$ \\
\hline
\end{tabular}

Table 2. Correspondence of land planning to the criteria of identification of social institutions

\begin{tabular}{|c|l|}
\hline \multicolumn{2}{|c|}{ Characteristic features of institutions and institutes } \\
\hline Roles & $\begin{array}{l}\text { From an ordinary land surveyor to the chief and head of a } \\
\text { land planning enterprise }\end{array}$ \\
\hline Utilitarian features & $\begin{array}{l}\text { Elements of land planning design methods, state } \\
\text { registration of land plots, cadastral accounting of lands and } \\
\text { land plots, land and land plots assessment }\end{array}$ \\
\hline Cultural symbols & $\begin{array}{l}\text { Land surveyor's day, specific certificates and certificates, } \\
\text { etc. }\end{array}$ \\
\hline Written codes & $\begin{array}{l}\text { Land and other codes, laws, methods, procedures, } \\
\text { standards, instructions, guidelines }\end{array}$ \\
\hline Oral codes & Informal norms of behavior of professional land managers \\
\hline $\begin{array}{c}\text { Attitudes and patterns of } \\
\text { behavior }\end{array}$ & Code of ethics of professional land managers \\
\hline
\end{tabular}




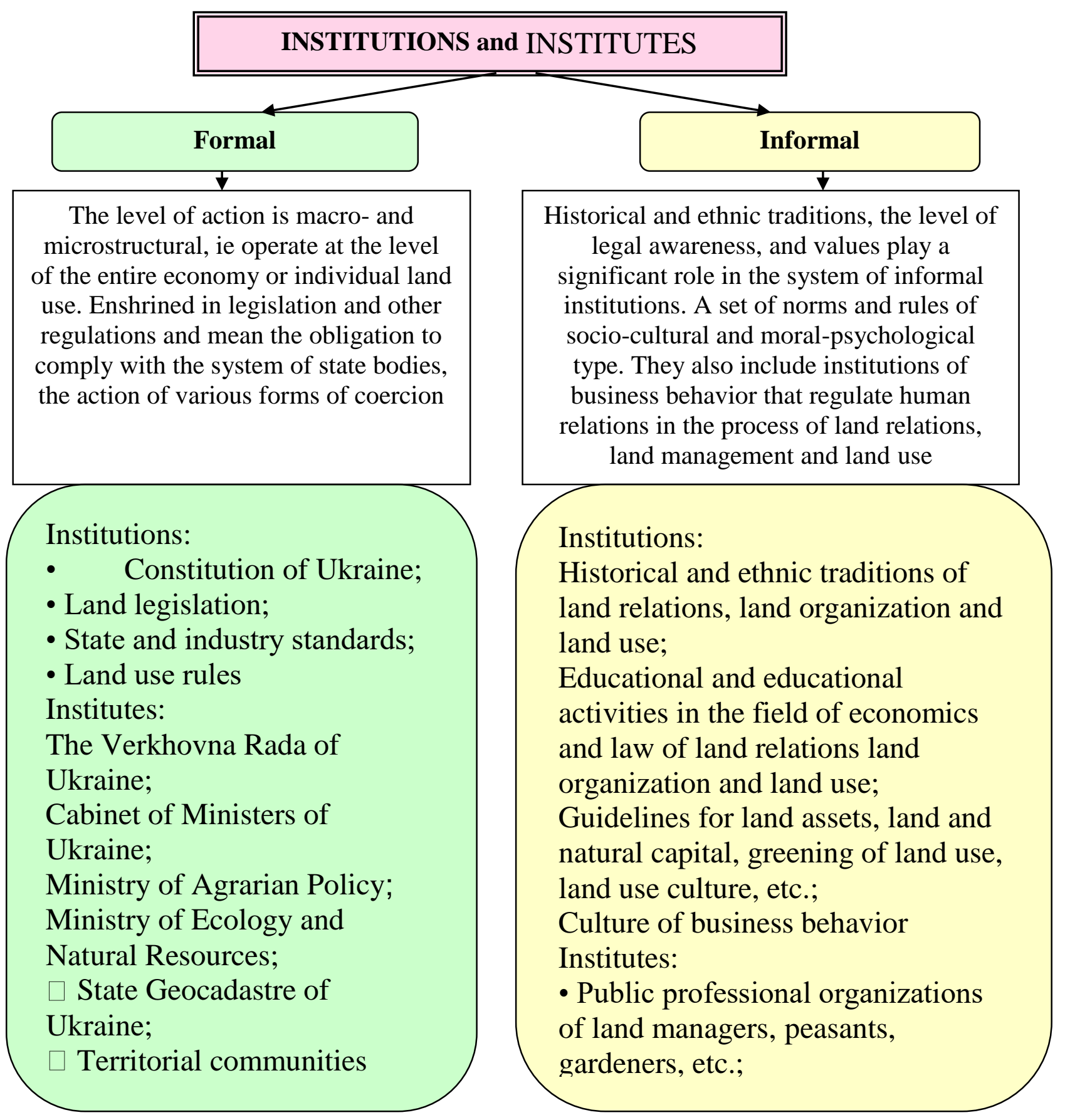

Fig. 2. Characteristics of types of institutions and institutes

Simplified the model of the socio-economic institution can be considered as a bipolar phenomenon. On the one hand, these are stable socio-cultural psychotypes of the involved people, which in theory is called an informal institution ("in people's heads"). On the other hand, these are formal institutions - the so-called "rules of the game", which are formalized in legislation, codes and other adopted documents. For the characterization of the Institution, its development, the informal component is 
decisive in theory. It is difficult to change and is more influential on the general condition of the Institution.

The interaction of these polar components of the Institution, forms inside of it certain organizations (institutional formations "somewhere outside"). Their success is based on the maturity and conformity of formal and informal institutions. All together, these are the only system that forms the socio-economic institution and the institute. With a balanced and developed condition of all components, this Institution and the Institute is successful or vice versa.

Thus, economic institutional theory explains the success or decline of certain countries in the global economy, certain institutions and Institutes inside the country [6]. Our proposed theory explains the effectiveness of the institution of land planning in the socio-economic system of Ukraine.

The model of the institution of land planning (developed from the standpoint of institutional theory) also distinguishes "pole" informal and formal components and formed under their influence organizations (or institutional formations - institutions) (Table 3).

Table 3. Functional model of land planning institution (classification, hierarchy and interaction of components)

\begin{tabular}{|c|c|}
\hline Way I & Way II \\
\hline \multirow{3}{*}{$\begin{array}{l}\text { 1. Informal institutions and } \\
\text { institutions (what is in the } \\
\text { "heads of people", stable } \\
\text { socio-cultural psychotypes) }\end{array}$} & 1.1. Professional land managers and land appraisers \\
\hline & 1.2. Landowners and land users \\
\hline & 1.3. Users of land cadastral information \\
\hline $\begin{array}{l}\text { 2. Professional land } \\
\text { management organizations }\end{array}$ & $\begin{array}{l}\text { 2.1. All-Ukrainian public organization "Union of Land } \\
\text { Surveyors of Ukraine", associations of land management } \\
\text { organizations and appraisers, etc. }\end{array}$ \\
\hline \multirow{3}{*}{$\begin{array}{l}\text { 3. "Educational" institutional } \\
\text { formations (methodical and } \\
\text { informational) }\end{array}$} & 3.1. Science \\
\hline & 3.2. Higher Education \\
\hline & 3.3. Professional land management publications, projects \\
\hline \multirow{4}{*}{$\begin{array}{l}\text { 4. Land management } \\
\text { structural units in institutions } \\
\text { and organizations }\end{array}$} & 4.1. Land policy \\
\hline & $\begin{array}{l}\text { 4.2. Organizational and management structures of executive } \\
\text { authorities, local governments, etc. }\end{array}$ \\
\hline & 4.3. Methodical support \\
\hline & 4.4. Organizational and technical support \\
\hline \multirow{3}{*}{$\begin{array}{l}\text { 5. Regulatory institutional } \\
\text { formations }\end{array}$} & 5.1. General purpose regulators (CMU, etc.) \\
\hline & $\begin{array}{l}\text { 5.2. Regulators for industry purposes (State Geocadastre of } \\
\text { Ukraine, etc.) }\end{array}$ \\
\hline & 5.3. Regulators for professional purposes (self-regulatory \\
\hline
\end{tabular}




\begin{tabular}{|c|c|}
\hline & $\begin{array}{l}\text { organizations in the field of land management and land } \\
\text { valuation) }\end{array}$ \\
\hline \multirow{4}{*}{$\begin{array}{l}\text { 6. Formal institutions ("rules } \\
\text { of the game") }\end{array}$} & 6.1. Legislation (codes, laws, methods, procedures, etc.) \\
\hline & 6.2. Concepts, programs \\
\hline & 6.3., Instructions, Standards, \\
\hline & $\begin{array}{l}\text { 6.4. Methodical recommendations, land management policy } \\
\text { of branch regulators, etc. }\end{array}$ \\
\hline
\end{tabular}

The proposed Model classifies, establishes the hierarchy and interaction of all components of the Land Management Institution. In it, of course, the determining factor is the component of the informal institution as a stable socio-cultural psychotypes, first of all, the land managers and, in addition, people who have an impact on their work and results (land planning measures and actions and land cadastral information). In the Model, the evolutionary impetus for development comes from an informal institution and through organizations (institutional formations - institutions) or with their help forms the "rules of the game" - a formal institution (path I Table 3). With this method, all components of the Institution are ready for the new "rules of the game", and first of all, the land managers. Under such conditions, the "rules of the game" will be followed. In institutional theory, this phenomenon is called "path dependence" - dependence on traditions, mentality, stable socio-cultural psychotypes. This is how we can explain the existence and differences of the Anglo-Saxon, German, American and other systems (institutions) of land planning.

On the other hand, institutional theory does not reject the revolutionary impulse of development by stimulating the necessary development of the Institution by adopting and imposing the desired "rules of the game" (way II table 3). However, such a path must be balanced against the available potential for change in the informal component (disregarding this explains the weak effectiveness of land management and land use reform in modern Ukraine).

Therefore, the skillful combination of evolutionary and revolutionary methods of the institutional model forms and ensures the effectiveness of land policies of the state or economic systems. Thus, in contrast to classical normative theories, the institutional theory of land planning creates a scientific foundation for effective 
reform of land relations and land use and, accordingly, the development of land management and land planning, land cadastre and as a result land use management, through knowledge of status, hierarchy and interaction of all components of the Institution of land planning.

The new theory considers land planning activity not as a limited, "technicaleconomic" or "normative-technical" System, but as a multifaceted social socioeconomic Institution, which, in contrast to theoretical ideas about the "Land Management System", grows not just new, but decisive for themselves organizational and social components of the "Institution of land planning ".

The Swiss Federal Polytechnic Institute of Zurich (Prof. I. Kaufmann and others) believes that land planning (Land Management) belongs to the types of spatial regulation activities and methods (tools) of political action [7]. In this case, as a tool of state and municipal activities, in their opinion, land planning should include: land use planning; actions to consolidate land plots, change land rights, land reclamation and landscaping, land transformation; land monitoring, navigation, geographic information, registration and cartographic systems; land surveying, geodetic surveys. More detailed model that defines the role and place of land management in land policy regarding the regulation of land relations and the organization of land use and protection in foreign countries is provided by scientists of the International Federation of Surveyors (FIG) led by Vice President Paul Van der Molen [8].

In his own earlier research, A.M. Tretiak [9] paid attention to the fact that on the basis of a systematic method for implementation of land policy on land use and its resources is land planning: land use development is planning, land relations are regulating, land is redistributing, easements are establishing, government interventions in the market sale and lease of land, taxation of land and other real estate. However, it is necessary to pay attention to the fact that institutional theory emphasizes: the informal component always remains decisive in the Institution. When considering land management as a "System", previous theories did not consider this determining factor of land management. There was no emphasis on classification, hierarchy and interaction of a wide variety of organizational 
components of land planning. At best, the range of these components was expanded by state (regulatory and administrative) regulation.

For supporters of normative theories, our institutional innovations may look like a certain enrichment of the modern essence of the "Land Management System". However, this theoretical and applied enrichment of the essence of the phenomenon of land planning is extremely important and important to consider it not so much "System" as "Institution".

At the same time, of course, there is no denying the existence of basic systemic foundations of land planning at the macro and micro levels of government. This is stated by A. Tretiak in the work "Land organization in Ukraine: Theory, Methodology" [2], where highlighting the logical connections and synergistic effect of the interaction of the elements of the System. However, more important for us is that the phenomenon of "land planning" grows from its closed subject-technicaleconomic to the socio-economic plane, and thus is recognized in theory as a socioeconomic institution.

Life changes the perception of the phenomenon of "land planning", expanding its components beyond the land and land use of enterprises, beyond the organizational, methodological, technical, environmental and economic, legal to social and professional-psychological fields. This increase in the quality of the components of "land planning" is explained only by the institutional theory of land management. The theory, which, above all, positions its essence with the discovery and explanation of the phenomenon of the Institution of land planning (land planning activities).

Thus, land planning is a socio-economic institution that provides trust, understanding and control in the socio-economic space, through professional processing, submission and interpretation for users of land information about the facts and processes of organizations (institutions). In the narrow perception of land management is the Institution of transformation using specific methods, rules (its formal component) and professional skills and judgments (informal component of the institution) of land planning facts in the language of numbers for understanding and 
control of all socio-economic space. In a wide sense, land management as an institution forms a certain face of land tenure and land use, state land institutions, public and other organizations (institutes) that organize and manage the use and protection of land and other natural resources and provide important information content of local, regional, national and global socio-economic spaces.

Therefore, it becomes clear that the phenomenon of the Institution absorbs the phenomenon of "System" of land planning (Fig. 3).

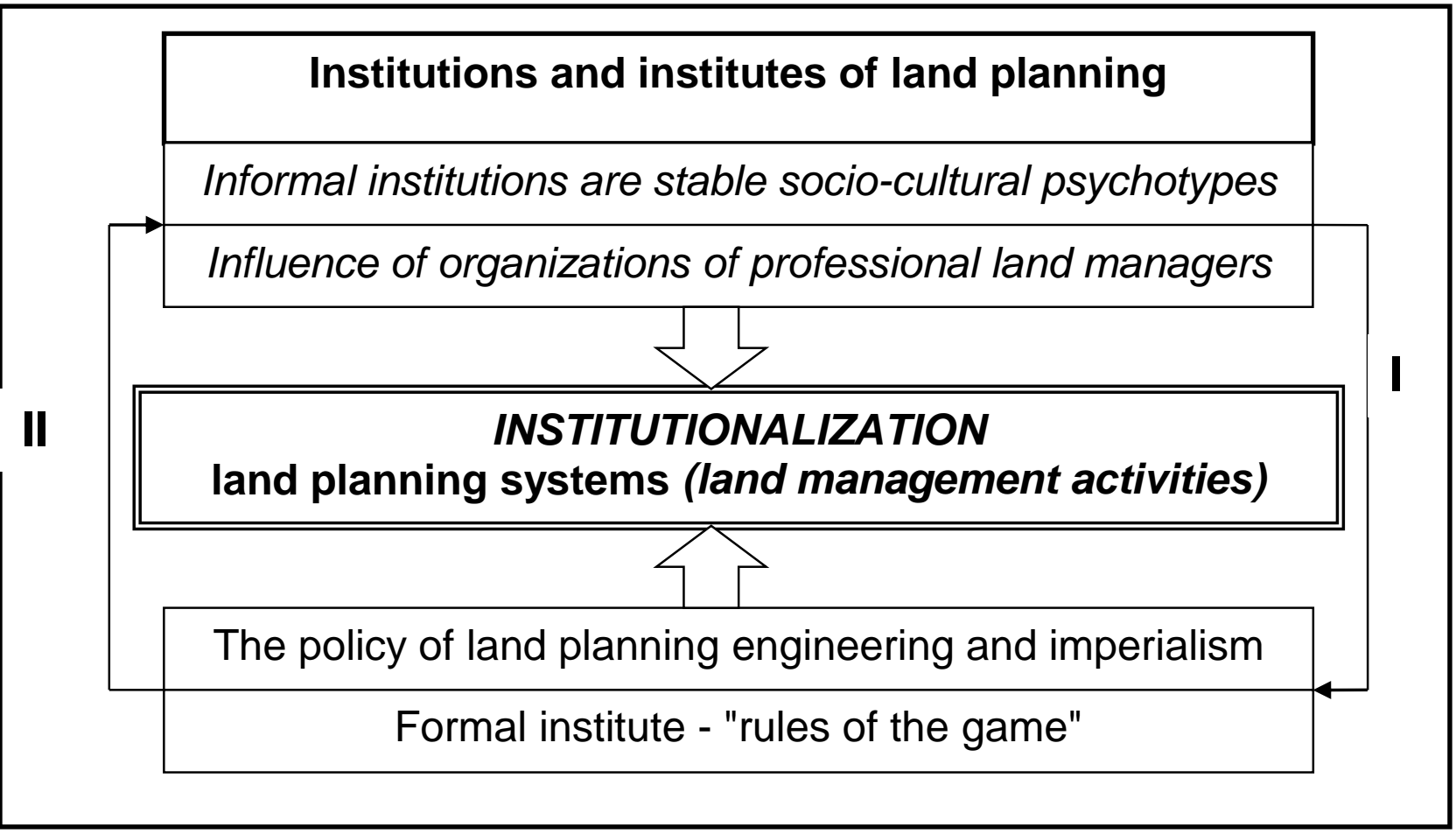

Fig. 3 Logical and substantive scheme of theoretical and applied enrichment of the "System" and the transformation into the "Institution" of land planning

From the outside it looks like an absorption process. At the same time, the methodological, technical and organizational levels of the Land Management System are being institutionalized by improving its qualitative characteristics. This is due to the synergy of the possibilities of a larger set of components in the "Institution" compared to the "System".

The institution of land planning is primarily characterized by the condition of the informal component, its ability through "organizations-institutions" (primarily associations of professional land managers) to influence the adoption and compliance 
with the "rules of the game". Influence the effective representation of management and economic activities in society (combination I, Fig. 3). This increase in theoretical ideas opens up new ways to develop land planning and, consequently, land reform actions. Its scientific and legal components ("rules of the game") are increasingly based on ideas, the influence of the professional environment, which should become more and more organized. On the other hand, the institutional theory of land planning opens the possibility and substantiates the need for application in land policy of state regulatory authorities, scientific schools, professional associations of land managers, the ideology of "land engineering" and "land imperialism" (combination II, Fig. 3). The United Nations Economic Commission for Europe links engineering to the innovative development of any activity.

Conclusions and prospects. The new institutional-behavioral theory of land planning (land management activities) is not a conjunctural changing of "signs" in land management science. From the "System", or from one of the functions of management, our activity grows to a separate important segment in the economic space - to the socio-economic "Institution". This is in line with the requirements of modern land planning practices and other challenges of the national and global economy. The need has matured in land planning to revise the fundamental guidelines for further development. In the science and practice of the developed world, there is no doubt about the objective basis of such a review. In Ukraine, the changes are more motivated by the undeserved secondary nature of the land surveyor's profession in the management environment and in economics. Thus, the training of land managers is carried out only in the field of technical sciences. However, even there the changing of theoretical ideas is motivated by the need for an adequate scientific response to the process of increasing the importance of land planning in the modern socio-economic space. The last one requires a transition to the training of land managers in the field of social and behavioral sciences and further research.

\section{References}


1. Tretiak A.M, Tretiak V.M. (2020). Conceptual foundations of a new institutional and behavioral economic theory for the land use economy of Ukraine. Modern problems in science. Abstracts of VIII International Scientific and Practical Conference (pp. 163-166). - Prague: Czech Republic.

2. Tretiak, A.M. (2013), Zemleustrij v Ukrayini: teoriya, metodologiya. [Land organization in Ukraine: theory, methodology]. Kherson: OLDI-PLUS, 488.

3. Tretiak, A.M. (2006). Koncepciya vdoskonalennya zemelnyx vidnosyn v Ukrayini [The concept of improving land relations in Ukraine]. Zemlevporyadnyj visnyk, 3, 27-30.

4. Ha-Yun, Chang. (2017). Ekonomika: instrukziya z vukorustannya [Economics: User Guide]. Kyiv, Ukraine, 400.

5. Hodgson, Jeffrey. (2003). Ekonomicheskaya teoriya i instituty: Manifest sovremennoy institutsionalnoy ekonomicheskoy teorii [Economic theory and institutions: Manifesto of modern institutional economic theory]. Moscow, Russia: Delo, 464.

6. North, D. (1997). Instituty. institutsionalnyye izmeneniya i funktsionirovaniye ekonomiki [Institutions, institutional change and the economy functioning]. Moscow, Russia: Nachalo, 190.

7. Kaufmann. (2007) (Switzerland). Land Management Opportunities for Sustainable Development, Provided by the Cadastre 2014 Approach // Report of the FIG Commission 7. Work shop in Quebec City (2748) www.

8. Molen, P.V.D., Silayo, E.H., Tuladhar A.M. (2008). Land Administration Policies and Systems. Comparative Study to Land Policy in 9 Countries in Africa and Asia. Stockholm, 6.

9. Tretiak, A.M. (2013), Konceptualni zasady «zemleustrij - 2030» [Conceptual principles of «land organization - 2030»]. Zemleustrij, kadastr i monitoryng zemel, $1-2,4-12$.

\section{А.М. Третяк, В.М. Третяк, Т.М. Прядка, Н.О. Капінос}




\section{ТРЕНД ІНСТИТУЦІОНАЛЬНОЇ ТЕОРІЇ РОЗВИТКУ \\ ЗЕМЛЕУСТРОЮ ТА ЗЕМЛЕВПОРЯДКУВАННЯ}

Анотація. Землевпорядна спеціалізація земельних відносин та системи землекористування значно посилила роль і місие землевпорядної діяльності $у$ розвитку економіки краӥни і ї̈ територій. Проте теорія розвитку землеустрою та землевпорядкування не встигає за запитами практики. Обмежено декларуються функиї, предмет $i$ об'єкти землеустрою та землевпорядкування. Тому метою дослідження визначено обгрунтування сучасного розвитку землеустрою та землевпорядкування в Україні на засадах новітньої інституціонально-поведінкової економічної теорії. Обгрунтовано, щуо землевпорядна діяльність (землевпорядкування) є сочіально-економічною інституцією, щуо забезпечує довіру, порозуміння $і$ керованість в сочіальноекономічному просторі, через професійну обробку, подачу і інтерпретацію для користувачів земельної інформації про факти $і$ процеси жстттєдіяльності організацій (інститутів). У вузькому сприйнятті землевпорядкування - изе Інституція трансформащзї з допомогою специифічних методів, правил (формальна ї̈ складова) $i$ професійних навиків $i$ суджень (неформальна складова інституиії) фактів землегосподарювання на мову циифр для порозуміння $і$ керованості усіх суб'єктів сочіально-економічного простору. $B$ широкому сенсі землевпорядна діяльність як Інституція формує певне обличчя землеволодінь $і$ землекористувань, державних земельних установ, громадських та інших організацій (Інститутів), щзо організовують та здійснюють управління використанням і охороною земель та інших природних ресурсів й забезпечують важливе інформащзійне наповнення місчевих, регіональних, національних $i$ глобальних соціально-економічних просторів. Інституція землевпорядкування пери за все характеризується станом неформальної складової, ї̈ здатністю через «організації-інститути» (в периу чергу об’єднання професійних землевпорядників) впливати на прийняття $i$ дотримання «правил гри». Впливати на ефективне представлення управлінської та господарської діяльності пов'язаною із землею в суспільстві. 
Цей приріст теоретичних уявлень відкриває нові иляхи розвитку землевпорядкування, а відповідно $і$ заходів земельної реформи. Його наукова $i$ нормативно-правова складові («правила гри») все в більшій мірі базуються на ідеях, впливі професійного середовищуа, щуо має стати все більщ організаційно об'єднаним. 3 іншого боку, інституиіональна теорія землевпорядкування відкриває можливість та обтрунтовує потребу застосування в земельній політиці державних регуляторних органів, наукових шкіл, професійних об'єднань землевпорядників, ідеології «землевпорядного інжинірингу» та «землевпорядного імперіалізму».

Ключові слова. Інституціінальна теорія, землеустрій, землевпорядкування, землевпорядна наука, землевпорядна діяльність.

\section{А.Н. Третяк, В.Н. Третяк, Т.Н. Прядка, Н.А. Капинос ТРЕНД ИНСТИТУЦИОНАЛЬНОЙ ТЕОРИИ РАЗВИТИЯ ЗЕМЛЕУСТРОЙСТВА И ЗЕМЛЕУПОРЯДОЧЕНИЯ}

Аннотация. Землеустроительная специиализациия земельных отношений и системь землепользования значительно усилила роль и место землеустроительной деятельности в развитии экономики странь и ее территорий. Однако теория развития землеустройства и землеупорядочения не успевает за запросами практики. Ограничено декларируются функции, предмет и объекты землеустройства и землеупорядочения. Поэтому целью исследования определень обоснования современного развития землеустройства и землеупорядочения в Украине на основе новейшей институц̧ионально-поведенческой экономической теории. Обосновано, что землеустроительная деятельность (землеупорядочение) является социиальнэкономическим институцуией, обеспечивающей доверие, взаимопонимание и управляемость в соцчиально-экономическом просторе, из-за профессиональной обработке, подаче и интерпретацуии для пользователей земельной информации о фактах и процуессах жизнедеятельности (институций). В узком восприятии землеупорядочения - это институция трансформацчии с помощцюю 
специифических методов, правил (формальная ее составляющая) $и$ профессиональных навыков и суждений (неформальная составляющуая институтьл) фактов землехозяйствования на язык циифр для понимания и управляемости всех субъектов социально-экономического пространства. $B$ широком смысле землеустроительная деятельность как институичия формирует определенное лицьо землевладений и землепользований, государственных земельных учреждений, общзественных и других организаций (институтов), которые организуют и осущуествляют управление использованием и охраной земель и других природных ресурсов и обеспечивают важное информационное наполнение местных, региональных, нащиональных $и$ глобальных социально-экономических пространств. Организация землеупорядочения прежде всего характеризуется состоянием неформальной составляющей, ее способностью через «организации-институтыл (в первую очередь объединение профессиональных землеустроителей) влиять на принятие и соблюдение «правил игры». Влиять на эффективное представление управленческой и хозяйственной деятельности связанной с землей в обществе. Этот прирост теоретических представлений открывает новые пути развития землеупорядочения, а соответственно и мероприятий земельной реформыл. Его научная и нормативно-правовая составляющчие («правила игры»)) все в большей степени базируются на идеях, влиянии профессиональной среды, которая должна стать все более организационным объединением. С другой стороны, институичональная теория землеупорядочения открывает возможность и обосновывает необходимость применения в земельной политике государственных регуляторных органов, научных школ, профессиональных объединений землеустроителей, идеологии «землеустроительного инжиниринга» и «землеустроительного империализма».

Ключевые слова. Институцчиональная теория, землеустройство, землеупорядочение, землеустроительная наука, землеустроительная деятельность. 